\title{
CTDNEP1 wt Allele
}

National Cancer Institute

\section{Source}

National Cancer Institute. CTDNEP1 wt Allele. NCI Thesaurus. Code C102889.

Human CT DNEP1 wild-type allele is located in the vicinity of $17 p 13$ and is approximately 8 $\mathrm{kb}$ in length. This allele, which encodes CTD nuclear envelope phosphatase 1 protein, is involved in the modulation of fatty acid phosphatases. 